\title{
Recepcja poglądów J. Deweya w polskiej pedagogice okresu międzywojennego
}

\begin{abstract}
Motto:

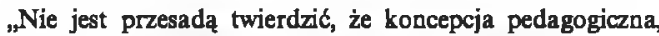
która szczyci się tym, ie przyjmuje idece wolności jako swą podstawę, może stać się równie dogmatyczna, jak koncepcja tradycyjna, którq zwalcza"
\end{abstract}

(J. Dewey, Demokracja $i$ wychowanie, Warszawa 1963, s. XXXIII - XXXIV)

Refleksja nad pedagogiką J. Deweya jest ciagle żywa i aktualna. Jego dorobek naukowy w zakresie pedagogiki stwarzał podstawę do alternatywnego i innowacyjnego myślenia o edukacji i pracy dydaktyczno-wychowawczej w szkole. Uwalniał od tradycyjnej szkoły, tradycyjnych metod ksztalcenia.

System pedagogiki stworzony przez J. Deweya był jednym z pierwszych systemów, który obronił się przed przesadnym psychologizowaniem i skrajnym pajdocentryzmem. Złożyły się na to m.in. pragmatyczna filozofia oraz doktryny socjologiczne, żywe na ówczesnym gruncie amerykańskim.

Ze sporu miedzy pajdocentryzmem a socjologizmem zrodził się system pedagogiczny, dość harmonijnie uwzględniający psychologiczny i socjologiczny aspekt wychowania. Polączenie tych dwóch aspektów wychowania pozwala nazwać jego poglądy o wychowaniu próbą socjopsychologicznej syntezy pedagogicznej ${ }^{1}$.

Mówiąc o źródłach systemu Deweya trzeba uwzględnić również jego zainteresowania praktyką wychowania. Jego filozofia była zabarwiona ciekawością wychowawcy - praktyka. To zainteresowanie dla spraw wychowawczych miało u niego szeroką rozpiętość. Zawierał się w nim w jednej osobie: nauczyciel zamiłowany w pracy szkolnej i wychowawca lubiący i rozumiejący dzieci. Z jednej strony można postrzegać Deweya jako subtelnego i wnikliwego wychowawcę, z drugiej zaś jako zawiłego w swej abstrakcyjności teoretyka pedagogiki.

J. Dewey zajmował się wszystkimi dziedzinami filozofii: logika, teoria poznania i metodologia nauk, etyka, antropologią estetyką oraz psychologią i socjologią. We wszystkich tych dziedzinach na czele stawiał „stosunek człowieka jako istoty aktywnej i dynamicznej do świata jako domeny ludzkiego działania i poznanian2.

Wedhug Deweya filozofia powinna dostarczać społeczeństwu jasno określone ideały, mające normować jego ustrój i dostarczać wizji przyszłości nadającej się do urzeczywistnienia ${ }^{3}$.

Pragmatystyczny naturalizm, instrumentalizm, problemowa teoria myślenia to podstawy dydaktyki J. Deweya. „Całe zagadnienie wychowania sprowadza Dewey do dziecka: jego siły powinny zostać ujawnione, jego zainteresowania powinny być urzeczywistnione, jego zdolności powinny rozwijać się"4.

${ }^{1}$ J. Dewey, Wybór pism pedagogicznych, Wrocław 1967, Rec. W. Czerniewski, „Kwartalnik Pedagogiczny” 1968 , nr 2, s. 322.

2 J. Dewey, Demokracja i wychowanie, Warszawa 1963, Rec. Graff Piotr, „Nowe Książki” 1964, nr 9, s. $407-408$.

${ }^{3}$ Por. J. Pieter, Johna Deweya myśli przewodnie o wychowaniu, "Chowanna" 1958, z. 5-6, s. 252. 
J. Dewey wychowanie rozumiał jako proces „wrastania jednostki w społeczną świadomość gatunku". Życie społeczne oprócz wychowującej miało pełnić także funkcję uspołeczniającą. Pod wpływem środowiska społecznego dziecko wyzbywało się egocentryzmu, stawało się istotą społeczną ${ }^{5}$. Szkoła, aby mogla stać się swoistą formą życia spolecznego musi spełniać 3 zadania:

1) ma upraszczać istniejące poza nią formy życia społecznego, wybierać tylko te, które odpowiadaja zdolnościom i dotychczasowym doświadczeniom dziecka;

2) przekazywać mlodemu pokoleniu to, co może przyczyniać się do powstania lepszego społeczeństwa;

3) ma być demokratyczna ${ }^{6}$.

Zmieniał się zatem ideał wychowawczy i punkt widzenia spraw dydaktyczno-wychowawczych. Szkoła uczyła współpracy i solidarności, pobudzała do twórczości i działania.

Dewey pisze: „patrzmy na dziecko takiem, jakim ono jest i jakiem być pragnie, wsłuchujmy się, jak bije w niem serce, jak drżą w niem pożądania i umieśćmy je w atmosferze zdolnej podtrzymywać i rozwijać jego ustrój fizyczny i moralny"7.

Pedagogika Deweya kryje w sobie genetyczne, funkcjonalne i społeczne przesłanki.

1) Genetyczne - wskazują na fakt, iż każde dziecko ma pewien uwarunkowany od wewnątrz zasób wrodzonych zainteresowań, a nauczyciel ma stworzyć odpowiednie warunki, aby te potrzeby rozwijały się;

2) funkcjonalne - bo ma służyć ogólnemu pożytkowi, a dziecko ma być wdrażane do pracy i działania stopniowo, środkami naturalnymi, które niesie życie;

3) społeczne - ponieważ dziecko jest członkiem społeczeństwa i do życia w nim i pełnienia określonej roli, powinno zostać przygotowane. Właśnie wychowanie ma tego dokonać. W wychowaniu dziecko jest punktem wyjścia, ośrodkiem i celem"8.

Dewey wskazuje na społeczną funkcję wychowania, polegającą na stopniowym przystosowywaniu się dziecka do wymogów życia społecznego, przez zapoznanie się z dorobkiem kulturowym społeczeństwa w trakcie zdobywania nowych doświadczeń i nawyków, eksperymentów. Zdaniem Deweya każde dziecko posiada 4 instynkty: instynkt twórczy, badawczy, socjalny i artystyczny. One moga dopomóc wychowawcy w wykryciu i oganizacji form aktywności dziecięcej. Wychowanie to wzbogacanie doświadczenia dziecka, które dziedziczy ono po pokoleniach starszych przez przebywanie $z$ innymi ludźmi i doskonalenie się pod wpływem wychowawców?.

Ciągłość życia społecznego wymaga stałego przygotowania młodego pokolenia do nieuchronnie następujących z upływem czasu zmian. Zmiany owe to nie tylko dorosłość, ale także tradycje i poziom szeroko rozumianej kultury. Stąd też niezwykle ważną w tych procesach rolę pełni wychowanie, stanowiące jeden $z$ istotnych elementów tych właśnie zmian. Wychowanie zatem nie może być jedynie rozwijaniem naturalnych dyspozycji dziecka, ani przystosowywaniem go do określonego społecznego ideału. Ma być przygotowaniem do pełnego wykorzystania uzdolnień i możliwości dziecka do udziału w przekształcaniu życia społecznego. W ustroju demokratycznym, gdzie nie ma barier społecznych, utrudniających wymianę doświadczeń międzypokoleniowych ${ }^{10}$, proces ten powinien przebiegać w sposób bardziej efektywny.

$\mathrm{Na}$ efektywność tę ma istotny wpływ proces poznania, który według Deweya „nie zachodzi między podmiotem a przedmiotem poznania $w$ tradycyjnym ich rozumieniu, ale między doświadczeniem wcześniejszym, nieuporządkowanym, chaotycznym, nieokreślonym a doświadczeniem późniejszym, uporządkowanym, określonym, zrozumiałym. W poznaniu chodzi jedynie o ustalenie

\footnotetext{
4 Bardach A., Socjologia wychowania Johna Deweya, „Glos Nauczycielski" 1958, nr 37, 8. 5.

"Por. L. Chmaj, Filozofia wychowania Johna Deweya, „Ruch Pedagogiczny" 1936/1937, nr 4/5. s. 130.

Tamże, s. 138-139.

7 J. Dewey, Szkola $i$ dziecko, Warszawa 1933. Wstęp i przet. H. Błeszyńska, Biblioteka Dzieł Narodowych,
} 8. 15 .

J. Dewey, Demokracja $i$ wychowanie, Warszawa 1963, s. $121-130$.

'A. Bardach, Socjologia wychowania Johna Deweya, "Głos Nauczycielski" 1958, nr 37, 8. 5.

10 J. Dewey, Demokracja $i$ wychowanie..., s. 145. 
takich cech rzeczy, zdarzeń i symboli, które mogą służyć do rozwiązania problemu"11. Zadaniem wychowania ma być „wychowanie ku myśleniu i przez myślenie" ${ }^{\text {" }}$.

Dewey podkreśla, iż „nikt nigdy nie umiał wyjaśnić, czemu to dzieci poza szkołą miewają tyle pytań, a dlaczego przeciwnie, okazują zdumiewający brak zainteresowania materiałem szkolnym? (...) Winę ponosi cały system wychowania. $\mathrm{Z}$ pozomie problemowego stać się musi prawdziwie problematyzacyjnym" ${ }^{13}$.

W nauczaniu potrzebne jest zarówno zaciekawienie ze strony ucznia, jak i dyscyplina, do której dziecko należy wdrażać od wczesnych lat życia. Problemy rodzą się z zainteresowania, a ich rozwiązanie warunkuje dyscyplina wewnętrzna. Materiał powinien nawiązywać do aktualnych potrzeb i zainteresowań uczniów. Dewey występuje przeciwko sztywnym podziałom materiału na poszczególne przedmioty, ujednoliconym programom, jednostronności i ograniczeniom systematycznego nauczania oderwanego od zajęć praktycznych. Metody nauczania mają odwoływać się do działalności i potrzeby tworzenia, pozwalające na różne formy twórczości dziecięcej ${ }^{14}$.

Zadaniem moralnym szkoły jest przygotowanie dziecka do panowania nad sobą, niezależności, zdolności przystosowywania się do zmian środowiska oraz wprowadzanie samemu w nim zmian pożądanych. Szkoła winna być dalszym ciągiem życia rodzinnego dziecka. Jako, że w rozwoju dziecka ważne w niej miejsce zajmowały działania manualne, stąd Dewey ujmował prace nie jako czynnik zewnętrzny, zagrażający swobodnemu rozwojowi indywidualnemu, a właśnie jako czynnik wewnętrznego rozwoju osobowości wskazując, że w pracy rozwijają się nie tylko umiejętności praktycznego działania, ale rozwijają się doniosłe zagadnienia moralne, naukowe, artystyczne. Dlatego też, według Deweya, „praca ręczna nie tylko zręczność rozwija i nie tylko ćwiczy umysł, lecz wprowadzana przez dorosłego nauczyciela, w sposób naturalny i bez wysiłku rozwija zmysł spoleczny"15.

Praca zatem stwarzała podstawy dla całościowego rozwoju osobowości. Stąd też głównym celem szkoły stało się rozwijanie myślenia, przygotowanie do skutecznego działania. Wiedza była potrzebna tylko o tyle, o ile zapewniała rozwój umiejętności działania. Między tymi umiejętnościami winna się też znaleźć umiejętność korzystania z wiedzy znajdującej się w książach, encyklopediach, podręcznikach, nie ma jednak sensu napełniania niq głów uczniowskich.

J. Dewey zrywa z systematycznym nauczaniem klasycznych przedmiotów szkolnych, ograniczając ich zakres do potrzeb wynikających z praktycznej działalności dzieci. Nie jest to równoznaczne z zaniedbywaniem wychowania intelektualnego. Rozwój umysłowy dziecka pragnie Dewey osiągnąć przez staranną analizę procesów myślowych, stwarzanie problemów do rozwiązania.

Zagadnienie spontanicznie przejawianej przez wychowanka aktywności, kwestia swobody i przymusu w procesie wychowania zostały w teorii J. Deweya powiązane z nowym ujęciem zainteresowania. „Zainteresowanie w interpretacji Deweya - pisze D. Gruelich - stanowiące początek rozwiązywania każdego problemu, przekształca się następnie w wysiłek dyscyplinujący jednostkę"16. Zainteresowanie ma być siłą wewnętrzną zmuszająca człowieka do podejmowania czynności, co stanowi podstawę dyscypliny w szkole.

Polscy pedagodzy okresu międzywojennego przyjmowali w większości bez zastrzeżeń szeroko pojętą deweyowską teorię zainteresowań. Uważali, że umiejętne kształtowanie u uczniów i wychowanków zainteresowań w odniesieniu do różnych dziedzin rzeczywistości, jest kształtowaniem najbardziej efektywnych wychowawczo wartości ${ }^{17}$.

11 T. Buksiński, Johna Deweya teoria badah́, „Studia Metodologiczne" 1981, z. 21, 8. 31.

12 J. Pieter, System pedagogiczny J. Deweya, Katowice 1946, s. 30-32.

13 J. Dewey, Jak myślimy? Warszawa 1957, s. 72.

14 J. Dewey, Wybor pism pedagogicznych..., 8. 49.

is J. Dewey, Szkola i dziecko, Warszawa 1933, s. 142.

16 D. Gruelich, Pojecie dyscypliny w pedagogice zachodniej, „Zeszyty Naukowe Uniwersytetu Lódzkiego", seria I, z. 6, Pedagogika i Psychologia, Lódź 1969, s. 123.

${ }^{17}$ Por. J. Sobczak, Recepcja idei "nowego wychowania" w polskiej pedagogice okresu miedzy wojnami, Bydgoszce 1979, Cz. II, s. $191-195$. 
To, że Dewey był Amerykaninem też stawiało jego koncepcję w innej optyce niż pedagogikę europejską. Cechy znamienne dla amerykanizmu wyrażające się gorączkowym ruchem, entuzjazmem dla pracy i przedsiębiorczości, pionierskie zdobywanie przyszłości, pewne lekceważenie dla tradycji - odzwierciedlają się również w twórczości Deweya i stały się warunkiem niezbędnym dla zwalczania rutyny szkolnej. Należy podkreślić również fakt, że Dewey był nie tylko wnikliwym myślicielem ale również reformatorem szkolnictwa ${ }^{18}$.

Zaprezentowane poglądy J. Deweya implikują szereg pytań, które szczególnie interesujące są w kontekście recepcji jego poglądów na gruncie polskim. Można je sformułować następująco: które $\mathrm{z}$ idei pedagogicznych J. Deweya stawały się szczególnie aktualne w warunkach oświatowych Polski okresu międzywojennego? Co miało wpływ na recepcję pedagogiki J. Deweya na gruncie polskim? Jacy pedagodzy i nauczyciele - praktycy popularyzowali twórczość J. Deweya, bądź w jakim stopniu na jego fundamentach rozwijali własne koncepcje pedagogiczne tak w teorii, jak i praktyce? Które elementy z teorii J. Deweya były negowane, krytykowane przez reprezentantów polskiej pedagogiki?

Recepcja twórczości naukowej J. Deweya na gruncie polskim przypada na okres międzywojenny. Jego prace były thumaczone na jezyk polski, co wpływało na popularyzowanie idei w myślach wychowawcy polskiego i w polskiej szkole. Ruch nowatorstwa dydaktycznego był inspirowany w dużym stopniu jego założeniami z zakresu teorii kształcenia, teorii wychowania czy organizacji pracy szkoły $w$ ogóle ${ }^{19}$.

Polscy pedagodzy okresu międzywojennego podkreślają konieczność zmiany sposobu wychowania jako następstwo szybkich przemian życia społeczno-kulturalnego oraz rozwoju gospodarczego. „Dostrzegają też, jak pisze Sobczak, iż zmiany gospodarczo-społeczne decydują pośrednio o nowym spojrzeniu na cel i sam proces wychowania, bowiem wywierają wpływ na rozwój nauk (szczególnie biologii i psychologii) oraz na ksztaltowanie się nowych poglądów filozoficznych, zwłaszcza pragmatyzmu i tzw. filozofii życia" ”o. Szczególna zasługa w ukazywaniu związków zachodzących między rozwojem społecznym, a przemianami szkoły i wychowania, w przeświadczeniu wielu naszych pedagogów przypada J. Deweyowi. Niejednokrotnie, jeśli nawet nasi pedagodzy nie powoływali się na J. Deweya, kierunek ich rozważań, sposób argumentacji wyraźnie wskazywały, że źródłem ich inspiracji były bezpośrednio lub pośrednio poglądy wybitnego amerykańskiego filozofa ${ }^{21}$.

Doceniali oni przełomowy charakter twórczości Deweya dla rozwoju światowej i polskiej literatury pedagogicznej. Wyrazem tych opinii może być wypowiedź L. Chmaja, który oceniając myśl pedagogiczną Deweya określał ją jako najwybitniejszą próbę "przystosowania szkoły do potrzeb i wymagań nowoczesnego życia spolecznego, stworzenia nowego typu wychowania jako narzędzia społecznej przebudowy w kierunku twórczego konstruktywnego demokratyzmu"22.

Zagadnienie szkoły $w$ kontekście przemian społeczeństwa amerykańskiego przedstawił J. Chałasiński. Analizując uwarunkowania przemian zachodzących w społeczeństwie amerykańskim, Chałasiński wskazywał na jej 2 cechy istotne: demokracje i „klimat wolności”. Do tworzenia tego „klimatu wolności” przyczyniła się, zdaniem naszego socjologa, uspołeczniona szkoła oparta na filozofii wychowania J. Deweya ${ }^{23}$.

Z. Mysłakowski, sceptycznie odnoszący się do ruchu nowego wychowania i niektórych koncepcji J. Deweya ${ }^{24}$, we wstępie do książki „Jak myślimy”? stwierdza: „Książce tej, której

${ }^{18}$ B. Nawroczyński, John Dewey w ZSRR $i$ USA, „Kwartalnik Pedagogiczny” 1965, nr 2, s. 49.

J. Dewey, Wybór pism pedagogicznych, Ossolineum 1967, s. 12-17.

20 J. Sobczak, "Nowe Wychowanie" w polskiej pedagogice okresu Drugiej Rzeczypospolitej (1918 - 1939) Bydgoszcz 1998, s. 384.

21 Tamzie s. 390.

22 L. Chmaj, Filozofia wychowania Johna Deweya, „Ruch Pedagogiczny" 1936/37, nr 4/5, s. 142.

${ }^{23}$ J. Chałasiński, Szkola w spoleczeństwie amerykańskim Warszawa 1936, 8. 538; s. X; J. Chałasiński, Demokratyczna filozofia spoleczenstwa w Stanach Zjednoczonych Ameryki Pótnocnej, "Kultura i Wychowanie" 1934, R. II, z. 1, s.21-23.

24 Z. Mysłakowski w rozprawie pt. Rozwój naturalny i czynniki wychowania, Kraków 1925 Odbitka „Kwartalnik Filozoficzny" 1925, T. III, s. 181-237, 257-285, dokonuje krytycznej analizy naturalizm! 
w krakowskim uniwersyteckim środowisku pedagogicznym używam od szeregu lat jako podstawowej w seminarium, zawdzięczam, wraz z moimi uczniami niejedną ostrą dyskusje, ale i niejeden płodny moment pedagogiczny"2s.

J. Pieter nazywa Deweya "Kantem w dziedzinie kultury wychowania" ${ }^{26}$. Za jedną z podstawowych twórczych idei systemu pedagogicznego Deweya Pieter uznaje położenie nacisku na sam proces rozwojowy dziecka, autonomię wychowania i idę̨ socjalizacji życia szkolnego ${ }^{27}$. Hasła dydaktyczne Deweya, jak w innym artykule stwierdza Pieter, „sq przede wszystkim wykwitem (i to wykwitem ostatnim a poniekąd i spóźnionym) prądów liberalistycznych wieku XIX, potem zaś dopiero tezami opartymi na psychologi”" ${ }^{28}$. W doktrynie Deweya dotyczącej tzw. aktów myślowych dostrzega Pieter więcej powiązań z pragmatyzmem niż konkretną wiedzą z psychologii myślenia.

Również we wstępie do „Zasad nauczania” (I wyd.) B. Nawroczyński stwierdza, iż J. Dewey był jednym $z$ autorów, którego twórczość miała największy wpływ na opracowanie jego książki ${ }^{29}$. Refleksja polskich pedagogów na temat zadań wychowania, wynikała $z$ faktu, że pozostawali oni pod wplywem nowych idei pedagogicznych J. Deweya. Np. B. Nawroczyński postuluje, aby wychowanie przygotowało do zgodnego $z$ wymaganiami demokracji i humanizmu współżycia społecznego. Według niego „wychowanie nie może i nie powinno być oparte wyłącznie na zasadzie swobody lub wyłącznie na zasadzie przymusu. Obydwie te zasady występują łącznie" 30 .

B. Nawroczyński uznaje wykształcenie za dobro kulturalne. Żywy proces kultury polega wg niego na tym, że jednostki zdobywając kulturę swego środowiska ciągłym i wytrwałym wysiłkiem, utrzymuja ja tym samym, przekształcają i rozwijaja. Wychowanie $\mathrm{i}$ nauczanie sq procesami społecznymi, zmierzającymi do czynienia z wychowanków tego spoleczeństwa kulturalnego, w którym im żyć wypadnie. Poza społeczeństwem i poza kulturą nie ma wychowania, ale bez osobowości nie jest możliwy ani rozwój społeczeństwa ani rozwój kultury ${ }^{31}$.

Wpływy koncepcji J. Deweya zauważyć można także w poglądach B. Suchodolskiego. Uważał on, że w wychowaniu trzeba uwzględniać naturę przeżyć społeczno-moralnych, a te „posiadaja dwoisty charakter obowiązku i pożądania, przymusu i swobody, opanowania i porywu, nakazu i miłości" ${ }^{32}$.

Zarówno B. Nawroczyński, B. Suchodolski, jak i mniej znani autorzy, idąc za myślą J. Deweya, przestrzegali, jak podkreśla J. Sobczak, „by w imię uwzględniania zainteresowań wychowanka nie oddawać się w procesie nauczania zbyt płytkiej i taniej radości, przestrzegaja przed opieraniem się na samorzutnych tylko zainteresowaniach młodzieży i podkreślają konieczność zaszczepiania nowych zainteresowań oraz konieczność wysilku ze strony wychowanków ${ }^{33}$. Problem rozwiązywania swobody i przymusu w pedagogice okresu miẹdzywojennego analizowany byl w odwoływaniu się m.in. do argumentacji J. Deweya, w której to dylemat swobody i przymusu miał być rozwiazywany tak, by zachować szacunek dla rozwoju osobowości wychowanka przy jednoczesnym przygotowywaniu go do życia zgodnego $z$ wymogami demokracji i humanizmu życia społecznego.

w wydaniu Rousseau, Deweya, Claparede'a i innych, podkrélając, iż zbyt duże znaczenie przywiazywali oni do czynników wewnętrznych w wychowaniu.

${ }^{25}$ Z. Mysłakowski, Wstęp do: J. Dewey, Jak myślimy? Lwów - Warszawa br. r. wyd.; Por. S. Baścik, Zyciorys naukowy prof. dra Zygmunta Myslakowskiego, w: Z. Myskakowski, Pisma wybrane, Warszawa 1977, s. 00.

26 J. Pieter, Twórczość pedagogiczna J. Deweya. „Kwartalnik Pedagogiczny” 1931, nr 3, s. 264.

27 Ibidem, s. 146, 262.

J. Pieter, Rozbieżnosci $i$ dysproporcje miedzy wiedza a praktyka wychowania $i$ nauczania, „Ruch Pedagogiczny" 1936/1937, nr 3, 8. 86.

ڤ B. Nawroczyniski, Zasady nauczania, Lwów - Warszawa 1930 (przedmowa).

30 B. Nawroczyński, Swoboda i przymus w wychowaniu, Warszawa 1932, s. 42.

31 L. Chmaj, Prady $i$ kierunki w pedagogice $X X$ wieku, Warszawa 1963, s. 399.

32 B. Suchodolski, Wychowanie moralno-spoleczne, Warszawa 1936, s. 19.

33 Sobczak, Nowe Wychowanie w polskiej pedagogice..., s. 369; Por.: Z. Krawczyński, Z rozważań nad wychowaniem nowego czlowieka, Kraków 1933, s. 39; J. Lechicka, M. Uklejska, Szkola w życiu codziennym, Warszawa 1935 , s. 230. 
Podobnie jak Dewey, „nowe wychowanie” traktowali jako formę przygotowania do życia społecznego H. Rowid, B. Nawroczyński, Z. Mysłakowski, B. Suchodolski, F. Znaniecki, J. Chałasiński czy J. Mirski. Propagowali oni wyższą formę aktywności, wyzwalającą instynkty twórcze, która wiązała się $\mathrm{z}$ idę tworzenia $\mathrm{w}$ szkole i społeczeństwie takich warunków, by działalność każdej jednostki była z jednej strony autonomiczna, a $z$ drugiej strony społecznie użyteczna. J. Chałasiński pisze: „demokracja według Deweya jest wyzwalaniem indywidualności ludzkiej, wyzwalaniem człowieka z krępujących go więzów..." ${ }^{4}$.

Chałasiński relacjonuje wykazane przez J. Deweya ujemne skutki istnienia w społeczeństwie dwu, odrębnych światów: świata pracy i świata konsumentów. Ten podział prowadzi do zmechanizowania pracy, do wyłączenia z niej ludzkich pierwiastków. Następstwem są przeciwieństwa teorii i praktyki, rozumu i doświadczenia, pracy i przyjemności, człowieka i natury, indywidualności i społeczeństwa ${ }^{35}$. Podstawą demokratycznego społeczeństwa powinna być twórcza praca fizyczna, wypływajaca $z$ pozytywnych zainteresowań emocjonalnych, intelektualnych i moralnych.

Inny polski pedagog, autor „szkoły twórczej”, H. Rowid, traktuje wychowanie jako funkcje uspołeczniania jednostki. Według niego „należyte społeczne i kulturalne wychowanie jest możliwe tylko w państwie o ustroju demokratycznym i społeczeństwie zorganizowanym na zasadach kooperacji" ${ }^{36}$. Również Lucjan Zarzecki odwołując się do różnych kierunków myśli filozoficznej i społecznej nowego wychowania, aprobuje deweyowską myśl na temat konieczności tworzenia środowiska uwzględniającego interesy dziecka i jego naturalne dążenia rozwojowe ${ }^{37}$.

Pod wpływem różnych teorii i obcych koncepcji kształtowały się poglądy naszych pedagogów dotyczących „szkoły pracy”. Duże zainteresowanie budziła deweyowska odmiana szkoły pracy, zwana "szkołą działania". Polscy pedagodzy, często powołując się na wybitnego pedagoga amerykańskiego, wskazywali J. Deweya jako tego, który przyczynił się do kształtowania ich koncepcji teoretycznych i projektów szkół realizujących proces dydaktyczny na ideach działania, pracy twórczej, samorządności młodzieży itp. ${ }^{38}$. J. Dewey, obok J. Kerschensteinera, został uznany za najwybitniejszego przedstawiciela szkoły pracy, traktowanej jako szkołe wychowująca, rozwijającą inicjatywę, samodzielność i charakter moralny ucznia ${ }^{39}$.

Idee J. Deweya wywarły wpływ zwłaszcza na eksperymentalne szkoły pracy w Polsce, dając wiele przesłanek teoretycznych pod ich funkcjonowanie ${ }^{40}$. Do najistotniejszych wartości wychowawczych i kształcących w koncepcjach „szkoły pracy" oraz jej odmianach, według B. Nawroczyńskiego, L. Zarzeckiego i H. Rowida, można było zaliczyć docenianie aktywności dziecka w procesie nauczania - uczenia się, rozwój jego twórczości i zainteresowań. Stąd też, jak sugeruje Nawroczyński, właściwe określenie nowej szkoły zawiera się w terminie zaproponowanym przez Deweya: „nauczanie przez działanie"41.

Podobnie W. Spasowski, ustosunkowując się do szkoły pracy przechodził pewną ewolucję uważając, iż początkiem jej było przyjęcie idei szkoły pracy pomyślanej w duchu Pestalozziego, a rozwiniętej przez Kerschensteinera, Deweya, Halfa, Laya. "Staje na stanowisku szkoły pracy pomyślanej w duchu Pestalozziego, rozwiniętej przez Kerschensteinera, Deweya (...) i rzecz oczywista w duchu najpiękniejszych tradycji polskiego życia i polskiej twórczości” ${ }^{42}$.

\footnotetext{
${ }^{34}$ J. Chałasiński, J. Dewey jako pedagog demokracji, „Ruch Pedagogiczny" 1927, nr 1, s. 15.

35 Tamże, s. 15.

36 H. Rowid, Podstawy $i$ zasady wychowania, Wanszawa 1957 , s. 58.

${ }^{37}$ L. Zarzecki, Wstęp do pedagogiki, Lwów - Warszawa 1922, s. $28-29$.

38 Por. T. Jatmużna, Pedagogika "szkoly pracy" w Polsce miedzywojennej i jej wplyw na ksztalcenie i doksztalcanie nauczycieli szkól powszechnych, Łódź 1983, s. 48-51.

${ }^{39}$ F. Kierski, Podreczna encyklopedia pedagogiczna, Lwów - Warszawa t. II, 1925, s. 547.

${ }^{40}$ Por. S. Dobrowolski, Realizacja twórczej myśli pedagogicznej w eksperymentach szkolnych w Polsce w okresie 1900-1939, w: Szkoly eksperymentalne w Polsce 1900-1964, Warszawa 19... 8. 109.

41 B. Nawroczyński, Zasady nauczania, wyd. 2, Lwów - Warszawa 1931, s. 13.

42 W. Spasowski, Wzorowe seminaria nauczycielskie. Kurs nauk szescioletnh, Warszawa 1920, w: Postepowa mysl oswiatowa w Polsce w latach 1918-1939, Wstep i opracowanie B. Lugowski i F. Araszkiewicz. Wrockaw 1972 , s. 204.
} 
Jednocześnie trzeba wskazać na fakt zgłaszania uwag krytycznych w stosunku do pewnych poglądów Deweya. Jednym z nielicznych przedstawicieli, który przestrzegał przed bezkrytycznym podchodzeniem do "szkoły pracy” J. Deweya był R. Taubenszlag. W rozprawie pt. „Ujęcie krytyczne zasad szkoły pracy Johna Deweya" (1929), R. Taubenszlag przyznawał szkole Deweya rolę historyczną w walce $z$ dotychczasowym werbalizmem, zwracał jednak uwage na pragmatyczne nastawienie twórcy szkoły. Stworzony przez pragmatyzm człowiek przedsiębiorczy, rzutki, obrotny pod względem praktyczno-życiowym nie odpowiadał jednak jego filozofii i poglądom. Do pozytywów pedagogiki Deweya zaliczał: uspołecznienie wychowanków, wartość pracy zespołowej, wdrażanie do ładu i porządku oraz samorządność młodzieży ${ }^{43}$.

Nie pomniejszając zasług J. Deweya, zarzucił mu zbytnią witalizację szkoły i ograniczenie się wyłącznie do wysilku fizycznego ${ }^{4}$. Jak pisal: „Umieszczenie szkoły w środku ogniska życiowego uważamy za zbyteczne, niedopuszczalne. Niebezpieczeństwa, na jakie narażamy młodzież, są większe i groźniejsze niż korzyści witalizacji” "45.

W polskiej pedagogice okresu międzywojennego często była formułowana myśl, by w procesie kształcenia stworzyć uczniowi takie warunki do działania, aby w sposób naturalny uczenie łączyło się z zabawą i praç̨. Znajdowało to swój wyraz w nowatorskich poczynaniach dydaktyczno-metodycznych, w pracach badawczych pedagogów, w eksperymentalnych szkołach, w innowacyjnej działalności nauczycieli. Koncepcja "szkoły działania" Deweya inspirowała wielu nauczycieli do podejmowania poczynań nowatorskich ${ }^{46}$.

I tak na przykład, jednym $z$ trwałych efektów nowatorskich poczynań R. Millerówny i M. Rostkowskiej był wydany w 1937 r. elementarz pt. „I klasa pracuje”, który może świadczyć o tym, jak wskazuje A. Maćkowiak, że obie autorki elementarza w swojej praktyce pedagogicznej starały się konkretyzować poglądy J. Deweya na zadania szkoły. Szkoła w ich koncepcji winna zbliżac się jak najbardziej do wychowania w rodzinie.

Podobnie eksperyment nauczania łącznego w Mosinie pod Poznaniem, prowadzony w latach 1931 - 1936 przez J. A. Maćkowiaków nawiązywał do metody projektów oraz koncepcji Deweya. Eksperymenty z Mosiny wysuwaja pod wpływem Deweya dwie zasadnicze formy organizowania pracy szkolnej dziecka w klasach początkowych: zabawę i prace ręczną ${ }^{47}$.

Odejście od nauczania podzielonego na odrębne jednostki lekcyjne z uwzględnieniem korelacji przedmiotowej znalazło swoje odzwierciedlenie w metodyce nauczania początkowego Ludwiki Jeleńskiej. Integracja nauczania, proponowana przez tę autorkę, została oparta na koncepcjach m.in. O. Decrolyego, J. Kerschensteinera, K. Linkego i J. Deweya ${ }^{48}$.

Również w metodyce nauczania początkowego F. Korniszewskiego i J. A. Maćkowiaków często spotykamy się z odniesieniami do naturalnych metod nauczania i wychowania preferowanych przez Deweya ${ }^{49}$. Do grona upowszechniajacego szkołę pracy należała dyrektorka Żeńskiego Seminarium Nauczycielskiego w Chełmie Lubelskim - Jadwiga Młodowska, która oprócz wdrażania systemu daltońskiego w Polsce propagowała założenia pedagogiki J. Deweya ${ }^{50}$.

Na samowychowanie, twórczość, poszanowanie osobowości wychowanka, rozwój dodatnich (pozytywnych) cech stawia J. Ostrowski w koncepcji tzw. „żywej szkoły”. Sądzi, że „szkoła

43 Por. T. Jalmużna, Pedagogika „szkoly pracy”... 8. $132-142$.

44 Por. R. Ciombor, Poglady spoleczno-pedagogiczne Rudolfa Taubenszlaga, w: Zapomniani pedagodzy lat miedzywojennych, Pod red. D. Koźmian, Szczecin 1997, s. 55-58.

is $\mathbf{R}$. Taubenszlag 0 jednostronności niektórych poczynań pedagogicznych wspólczesnej epoki. Odbitka z "Ruchu Pedagogicznego" Książnica Atlas, Warszawa 1930, s. 339.

46. Bereźnicki, Innowacje pedagogiczne w Polsce (1918-1939), Szczecin 1984, s. $24-25$.

47 Por. A. Maćkowiak, Nauczanie laczne dawniej i dzis, Poznań 1970, s. 80-90.

48 Por. L. Jeleńska, Metodyka pierwszych lat nauczania, Warszawa 1926; L. Horyń, Poglady pedagogiczne Ludwiki Jeleńskiej (1885-1961), w: Zapomniani pedagodzy lat międzywojennych, Pod red. D. Koúmian, Szczecin 1997, s. $182-183$.

49. Forniszewski, J. A. Maćkowiakowie, Nauczanie poczqtkowe - psychologia - dydaktyka - praktyka, Warszawa 1938, „Z praktyki szkolnej" $\mathrm{Nr} 34$, s. 25-26.

so Por. T. Jahmużna, Pedagogika "szkoly pracy" w Polsce miedzywojennej..., Lódź 1983, s. 145-147. 
rzeczywiście wychowująca oprzeć się musi zarówno na zdobyczach i wskazaniach szkoły na wsi, jak szkoły czynu Deweya" 51. Poglądy J. Ostrowskiego w dużej mierze były zbliżone do "szkoły działania” J. Deweya. W „żywej szkole” Ostrowskiego kładzie się nacisk na rozwój aktywności młodzieży, przejawiającej się w różnorodnych zajęciach praktycznych. Podstawowa funkcja tych zajeć miała polegać na nauczeniu uczniów samodzielnej pracy i przez to zdobywanie wiedzy na drodze samodzielnego wysiłku umysłowego ${ }^{52}$. J. Ostrowski daje zalecenia, aby nie wymuszać zainteresowań, ale je budzić ${ }^{53}$.

Twórczość pedagogiczna Deweya znajdowała się również w kręgu zainteresowań władz oświatowych. Dowodem na to moga być przeprowadzone badania ankietowe przez A. Zieleńczyka, pracownika Ministerstwa WR i OP wśród 400 nauczycieli polskich na temat realizacji idei samorządu w Polsce. W badaniach tych nauczyciele wskazywali na lektury autorów, które inspirowały ich do stosowania tej formy pracy z młodzieżą. Obok polskich autorów, takich jak Przanowski, Szczawińska, Rowid, Nawroczyński podkreślano wpływy Foerstera i Deweya ${ }^{\text {s4 }}$.

Analizując system nauczania Decroly'ego, M. Lipska-Librachowa porównuje cechy istotne jego koncepcji z właściwościami systemu M. Montessori, J. Deweya i J. Kerschensteinera. Wyraźnie podkreśla, iż system Deweya góruje nad innymi, ponieważ cechuje go wiara w autentyczne zainteresowania dzieci i możliwości ich wykorzystania w procesie uczenia się w powiązaniu z zasadą dostosowania nauczania do ich poziomu umysłowego i okresu rozwojowego ${ }^{55}$.

Na związki i wpływy twórczości J. Deweya wyraźnie wskazuje teoretyczne opracowanie przez J. Krystanowskiego nowej propozycji sposobu nauczania historii. Opracowan̨ przez siebie metodę autor zalicza do „systemu szkoły pracy głównie pedagogiki amerykańskiej”. ${ }^{56}$. Kierowanie samodzielnością i świadomością uczenia się, rozwój krytycyzmu i zdolności dokonywania operacji myślowych, wyrabianie poczucia odpowiedzialności za działanie ucznia - to zbieżne momenty procesu nauczania - uczenia się J. Deweya i Krystanowskiego ${ }^{77}$.

Gdyby postawić pytanie o wierność rozumienia myśli Deweya i sposoby recepcji jego dzieł pedagogicznych przez ówczesnego nauczyciela - wychowawcę, należy zaznaczyć, iż nie chodziło tu o prostą recepcje tekstu czy teorii J. Deweya, w sensie jego odczytania czy też literalnego zrozumienia. Chodziło zatem o swego rodzaju dialog odbiorcy z dziełem, o przeniknięcie głównych idei $w$ umysłach pedagogów $z$ równoczesnym ich zaowocowaniem $w$ ówczesnym działaniu nauczycieli. Dzieła Deweya były nasycone wartościami inspirującymi w większym stopniu niż inne koncepcje pedagogiczne przełomu XIX/XX wieku. Aktualność jego koncepcji była szczególnie podnoszona w praktyce i teorii pedagogiki polskiej okresu międzywojennego. Ale jednocześnie jego aktualność jest widoczna we współczesnych warunkach tworzenia się polskiej demokracji i nowych założeń systemu oświatowego. Uwidacznia się to w praktyce edukacyjnej, m.in. w poszukiwaniach alternatywnych rozwiązań przy organizowaniu nowych szkók.

Teoretyczny rodowód poglądów wielu przedstawicieli polskiej pedagogiki II Rzeczypospolitej tkwi min. w Deweyu. Interpretacja $\mathrm{i}$ analiza jego przesłanek teoretycznych dotyczyła zarówno rodowodu filozoficznego idei pedagogicznych, jak i założeń doktrynalnych. Wyniki owych analiz były zamieszczane w syntetycznych opracowaniach książkowych oraz artykułach takich autorów, jak: K. Sośnickiego, B. Nawroczyńskiego, S. Hessena, J. Pietera, J. Chałasińskiego, B. Suchodolskiego, M. Ziemnowicza oraz wielu wybitnych nowatorów - praktyków. Osoby te pragnęły teoretyczny dorobek progresywizmu pedagogicznego włączyć do modernizacji procesu dydaktyczs. 46 .

51 J. Ostrowski, Żwa szkola (Zarys organizacyjny i metodyczny przyszlej szkoly średniej), Warszawa 1927,

52 Por. F. Bereźnicki, Hasła „nowej szkoly" w dydaktyœ Drugiej Rzeczypospolitej, Toruń 1998, s. 102 - 103.

${ }^{53}$ J. Ostrowski, Zywa szkola, Warszawa 1927, s. 36.

54 Sobczak, "Nowe Wychowanie" w polskiej pedagogice... s. 311-312.

55 Sobczak, s. 227; M. Lipska-Librachowa, Slowo wstępne do: A. Hamaide, Metoda Decroly, tk. M. Górska. Warszawa - Lódź 1926, s. 17.

56 J. Sobczak, s. 250; J. Krystanowski, Metoda szkiców i zagadnień (z cyklu: Wychowanie intelektualne w nowej szkole), Lwowska Biblioteka Pedagogiczna. Lwów 1936, s. 4.

57 Ibidem, s. 18. 
no-wychowawczego szkoły polskiej. Można zaliczyć do tej grupy takie nazwiska, jak H. Rowid, J. Ostrowski, R. Taubenszlag, W. Spasowski, A. Maćkowiak, A. Gorzycka-Wieleżyńska ${ }^{58}$. Udział pedagogów - teoretyków i nauczycieli w procesie upowszechniania progresywizmu pedagogicznego przyczynił się do podjęcia próby analizy nowej wersji procesu nauczania opartej na rozwoju zainteresowań i strony wolicjonalnej ucznia.

Wprowadzenie na nowe drogi syntezy w nauczaniu oraz teorii stopni nauczania opartej na analizie myślenia, B. Nawrozzyński przypisuje Deweyowi. Według niego, tok poszukujący nauczania sformułowany przez Deweya jest stosunkowo mało ogólny, ponieważ opiera się jedynie na dwóch rodzajach rozumowania: tłumaczeniu i sprawdzaniu, a nie obejmuje już np. wnioskowania i dowodzenia. Poza tym „poszukująca i podająca forma nauczania muszą się nawzajem wspierać i uzupełniać" ${ }^{59}$. Nie można procesu uczenia się, jak to czyni Dewey, utożsamiać z procesem badania. Poza tym stopnie formalne Deweya, zdaniem Nawroczyńskiego, za mało uwzględniają potrzebę utrwalania $w$ umyśle uczniów osiągniętych wyników oraz przerabiania wiedzy $w$ umiejętności.

Poza tym B. Nawroczyński zwracał szczególną uwagę na aktywną postawę uczniów w procesie nauczania. W związku z tym domagał się, aby nauczanie było zastępowane uczeniem się uczniów. Podkreślał konieczność „wzbogacania rodzajów nauczania i uczenia się przez wprowadzanie pracy laboratoryjnej, warsztatowej, różnego rodzaju ćwiczeń i wycieczek oraz lekcji prowadzonych zgodnie z systemem J. Deweya" ${ }^{00}$. Jednocześnie należy podkreślić, że analiza i krytyka stopni formalnych J. Deweya stała sį podstawą dla Nawroczyńskiego do sformułowania własnego schematu toku nauczania poszukującego, dostosowanego do heurystycznej formy lekcji ${ }^{5}$.

Inny dydaktyk polski, K. Sośnicki, w mającym teoretyczno-praktyczny charakter „Zarysie dydaktyki” z 1925 roku, analize zagadnień dydaktycznych zaczynał od charakterystyki kształcenia i nauczania jako czynności. Pojęcie „czynności” czynil podstawowym i nadrzędnym terminem dydaktyki. Można przyjąć, iż takie rozumienie nauczania i kształcenia jako czynności wiąże się z dhugoletnią praktyką autora i wpływem, „szkoły działania” J. Deweya ${ }^{62}$. Podjęta analiza struktury lekcji i metody nauczania ze szczególnym uwzględnieniem uczenia się naturalnego uwidacznia wpływy J. Deweya. Nauka szkolna miała się stać dla ucznia przeżyciem poprzez ścisłe połączenie strony uczuciowej i umysłowej ${ }^{63}$. K Sośnicki opowiadał się za naturalnym i twórczym uczeniem sį w oparciu o stadia rozwiązywania problemów wyraźnie nawiązując do przethumaczonej na język polski pracy J. Deweya „Jak myślimy”64. W podobny sposób swego rodzaju intelektualizm pedagogiczny zaczerpnięty z amerykańskiej szkoły pracy J. Deweya odzwierciedla system pedagogiczny S. Dobrowolskiego, nawiqzzujący głównie do dzieła „Jak myślimy?" 65 .

Gdyby podjąć próbę lapidarnego zrekapitulowania problemu recepcji poglądów J. Deweya, należy podkreślić, iż w wielu wątkach myśli te są zbieżne ze współczesną refleksją humanistyczną. Jego koncepcja miała charakter edukacji nierepresyjnej i emancypacyjnej. Wartością niekwestionowaną zaś jego dydaktyki była aktywność i samodzielność ucznia w procesie uczenia się, odpowiedzialność za siebie, nabywanie wiedzy nie tylko deklaratywnej ale przede wszystkim kontekstowej. Wydaje się, że stawianie na tego rodzaju podstawy w połączeniu z praca twórcza, pasjonująca ucznia $w$ procesie nauczania, $w$ zespoleniu $z$ budowaniem więzi $z$ otoczeniem społecznym i przyrodniczym jest mechanizmem, który zawsze będzie cechował szkołę i czynił pedagogiczne poglądy Deweya przydatnymi i aktualnymi także dla nauczyciela XXI wieku.

5. Michalski, Praca naukowo-badawcza nauczycieli w Drugiej Rzeczypospolitej, Poznań 1994, s. 9.

59 B. Nawroczyński, Zasady nauczania, wyd. 2 Lwów - Warszawa 1931, s. 266.

${ }^{60}$ F. Bereźnicki, Hasla ,nowej szkoly".., 8. 35.

61. Ibidem, s. 36-37.

62 F. Bereźnicki, Hasla ,nowej szkoly"... 8. 41.

63 Por. K. Sośnicki, Dydaktyka ogólna, odbitka z Encyklopedii Wychowania, Warszawa 1935, s. 122.

${ }_{64}$ J. Dewey, Jak myslimy, przekład Z. Bastgenówna, Lwów - Warszawa br. r. wyd. Informację o przygotowaniu do druku ksiązki J. Deweya "Jak myslimy” znajdujemy w: „Wychowanie $i$ nauczanie. Przewodnik do Wydawnictw Pedagogicznych i Dydaktycznych S.A. Ksiażnica Atlas TNSW, opracowali Jan Piątek i K. Sośnicki, Lwów - Warszawa 1932, s. 35; Sobczak, 8. $209-210$.

${ }_{65}$ W. Okoń, Wizerunki slawnych pedagogów polskich, Warszawa 1993, s. 79. 